\title{
INFLUENCE OF CHEMICAL POLYMER ADDITIVE ON THE PHYSICAL AND MECHANICAL PROPERTIES OF EXPANDED POLYSTYRENE CONCRETE
}

\author{
John Wasiu*, DaOud Mohammad Baba \\ Afe Babalola University, College of Engineering, Department of Civil Engineering, P.M.B. 5454, 23400 \\ Ado-Ekiti, Ekiti state, Nigeria \\ * corresponding author: wasiu.john@edouniversity.edu.ng
}

\begin{abstract}
This research investigated the effect of Renolith chemical polymer additive (RCPA) on the properties of expanded polystyrene (ESP) concrete. Renolith chemical additive is a polymer-based product in a liquid form made up of latex and cellulose. Polystyrene panels were collected as a waste materials and grinded into smaller beads. An experimental investigation was carried out on the EPS replacement ranging from $0 \%$ to $100 \%$ on the M30 (C25/C30) mix design. Engineering properties, such as workability, density, water absorption, compressive strength, split tensile strength, and flexural strength tests, were studied for both the conventional and EPS concrete. The results indicate that workability increases with increasing amount of EPS contents. Water absorption, compressive, tensile, and flexural strength yielded a satisfactory result at 0-50\% replacement. The density of the EPS concrete at $0-37.5 \%$ replacement revealed similar values to a conventional concrete; and light-weight concrete $\left(1817.5-1030 \mathrm{~kg} / \mathrm{m}^{3}\right)$ was achieved at a $50-100 \%$ replacement. Generally, the addition of the RCPA to the concrete mix has caused an improvement in the properties of the EPS concrete. It was concluded that EPS beads can be used as a partial replacement for coarse aggregates in the production of both structural light-weight and dense concrete. The replacement of coarse aggregate with EPS beads showed a positive application as an alternative material for the construction industry.
\end{abstract}

KEYWORDS: Expanded polystyrene (EPS), waste material, concrete, light-weight concrete, density, compressive strength.

\section{INTRODUCTION}

Concrete has been in use for centuries and it is the most commonly used material in building construction and civil engineering structures. The word concrete comes from the Latin word concretus, meaning "mixed together" or "hardened". Concrete is a civil engineering material resulting from the mixture of cement, coarse and fine aggregates and water. Sometimes, admixtures may be added to modify one or more properties in the fresh and/or hardened state of the concrete. Such a material, when properly batched and thoroughly mixed, sets through the process of hydration and hardens into a concrete mass that can withstand compressive stresses. According to Oyenuga [1, normal-weight concrete has a density equal to $2400 \mathrm{~kg} / \mathrm{m}^{3}$ while a light-weight one from 160 to $1920 \mathrm{~kg} / \mathrm{m}^{3}$.

The high density of concrete causes the dead load of a conventional concrete to be very high. This heavy self-weight makes it uneconomical as a structural material. To reduce this dead load, there is a need to use the light-weight concrete. This can be used for non-structural members like wall panels, concrete fascia, etc. Thus, it enhances construction progress; the weight of a building on the foundation is an important factor in design, particularly in the case of weak soil and high-rise structures. In a framed structure, the beams and columns have to carry loads of the slabs and walls. If these elements (slabs, walls etc.) are made of a light-weight concrete, it will result in a considerable reduced cost. The light-weight concrete can be achieved in a number of ways, either by introducing gas (or foam) or by replacing the standard aggregates with lighter materials. In this paper, the latter approach was used. The coarse aggregate is replaced in volume by Expanded Polystyrene (EPS) beads.

\section{LiterATURE REVIEW}

Expanded Polystyrene (EPS) is a general term for copolymers of polystyrene and styrene. It is a rigid cellular plastic foam material derived from by-products of petroleum and natural gas. EPS is one of the lightest of all construction materials, that makes it easy to handle and it brings about a faster construction time. Its outstanding thermal insulation properties and durability ensure a full lifetime performance of the building or construction application in which it is used.

EPS beads are very light, white color, fire retardant, pearl shaped, closed cell. They are made up of about $98 \%$ of air and $2 \%$ of polystyrene. Therefore, they are extremely safe and above all, non-toxic. The diameter of beads normally varies between 3 to $12 \mathrm{~mm}$ with an 
apparent density of $8-15 \mathrm{~kg} / \mathrm{m}^{3}[2$. The expanded polystyrene aggregate is commercially available with an appropriate chemical coating, which is necessary to achieve a uniform dispersion in the mixture of fresh concrete and to avoid segregation during concrete mixing and handling.

In structural design, the self-weight of concrete takes a high proportion of the load. In locations with poor soil - resulting in a low bearing capacity, the weight of concrete makes it necessary to modify the foundation of the structure. In some cases, pile foundations are required - and they incur additional construction cost. This research seeks to find an alternative to the conventional concrete used for construction, which would reduce the weight of the structure while retaining its structural integrity.

The best environmental solution for waste materials is the re-use and recycling them. Expanded Polystyrene (EPS) is one of such waste materials. A large quantity of polystyrene is disposed in landfills or dumped in open spaces (as waste) because it is hard to decompose. This contributes to environmental pollution and can be harmful to the eco-system. National and international environmental regulations have also become more inflexible, resulting in an increasingly costly disposal of this waste. This study seeks to compare the engineering characteristics of a conventional concrete to the Expanded Polystyrene (EPS) concrete and ascertain if the latter is a suitable substitute for a construction work.

Jayalekshmi and Reddy 3] studied the effect of polymer based chemical (Renolith) on treated clay soil. Their studies revealed that polymer based chemical as well as enzymes stabilizers are necessary to improve road conditions. Some of these enzymes includes Fujibeton, Terrazyme and Renolith. The application of Renolith in their research showed an improvement in California Bearing Ratio (CBR) and compressive strength of the clayey soil.

Quadri et al 4 carried a research on the Renolith Appraisal on Lateritic Soils along Oshogbo-Iwo road in South-west Nigeria. They apply the polymer based chemical on the lateritic soils for stabilization. Their findings showed an improvement of the CBR by approximately $40 \%$. They conclude that Renolith is effective in improving soil properties up to the sub-base material.

Jamal and Kumar [5] worked on the effect of Renolith treated black cotton soil for sub-grade pavements. Their findings revealed an improvement of the clayey soil properties. There are many natural lightweight materials that can be explored for the production of a lightweight concrete. They include materials like expanded glass, clay and shale.

Kumar and Prakash [6] studied the effect of lightweight concrete (LWC) and normal weight concrete (NWC) on compressive strength and density by replacing coarse aggregates with cinder and light expanded clay aggregates (LECA). Their research

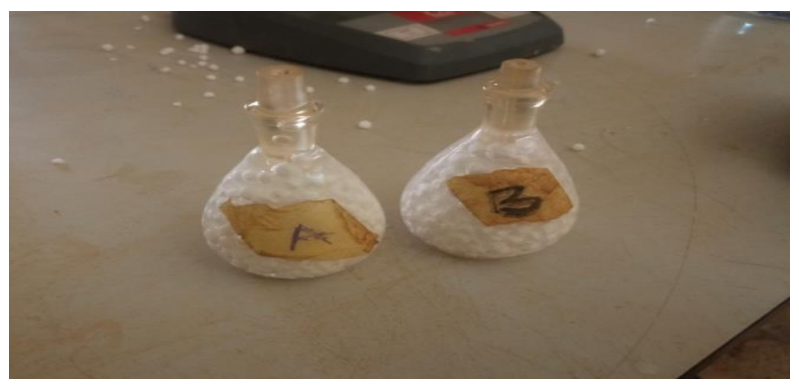

Figure 1. Polystyrene beads in pycnometer.

revealed an improvement in compressive strength $\left(39.2 \mathrm{~N} / \mathrm{mm}^{2}\right.$ for $\mathrm{LWC}$ and $43.4 \mathrm{~N} / \mathrm{mm}^{2}$ for $\left.\mathrm{NWC}\right)$ and densities (between $1800-1950 \mathrm{~kg} / \mathrm{m}^{3}$ for LWC and $2637 \mathrm{~kg} / \mathrm{m}^{3}$ for NWC). For concrete to be considered as structurally light-weight material, the minimum compressive strength at 28 days curing should be $17 \mathrm{~N} / \mathrm{mm}^{2}$ and density between $1440-1840 \mathrm{~kg} / \mathrm{m}^{3}$. [7]

\section{Methodology}

\subsection{EPS WASTE}

The EPS was collected in panels as a waste material around Afe Babalola University, Ado-Ekiti (ABUAD), Ekiti State. The panels were grinded into smaller beads (EPS beads) with the aid of a wire brush as in Fig. 1. The most common type of cement in Nigeria is the Ordinary Portland Cement (OPC) of grade 42.5 (Dangote brand), obtained from Ado-Ekiti. It was used as a binder conforming to the requirements of BS 197-1 8. The physical properties are shown in Table 1 The aggregates used can be classified as fine and coarse. For the first one, clean and dried river sand obtained from Ado-Ekiti was used. Table 2 shows its physical properties. While for the coarse aggregate, crushed granite stone of nominal size of $20 \mathrm{~mm}$ was used. Table 3 shows its physical properties. The water used for the mix was locally supplied within ABUAD. It was ensured that the water used was clean and free from any impurities.

The particle size distribution, specific gravity, water absorption, and aggregate impact tests were determined in accordance with BS 812-103.1 [9], BS 812-Part 2 [10, and BS 812-112 [11. Fig. 2] shows the plots for the particle size distribution of the Coarse and Fine aggregates used. The reinforcement bars used for the reinforced concrete beam samples subjected to bending tests are $10 \mathrm{~mm}$ in diameter as shown in Fig. 3

\subsection{Polymer BASED ADDITIVE}

The are different polymer chemical additives used in the costruction industry. Renolith chemical polymer additive (RCPA) is a polymer-based product made up of latex and cellulose. It is available in a liquid form. This is the secondary binder because it produces the stabilizing effects on its own without the presence of cement or any other activator. It reacts 


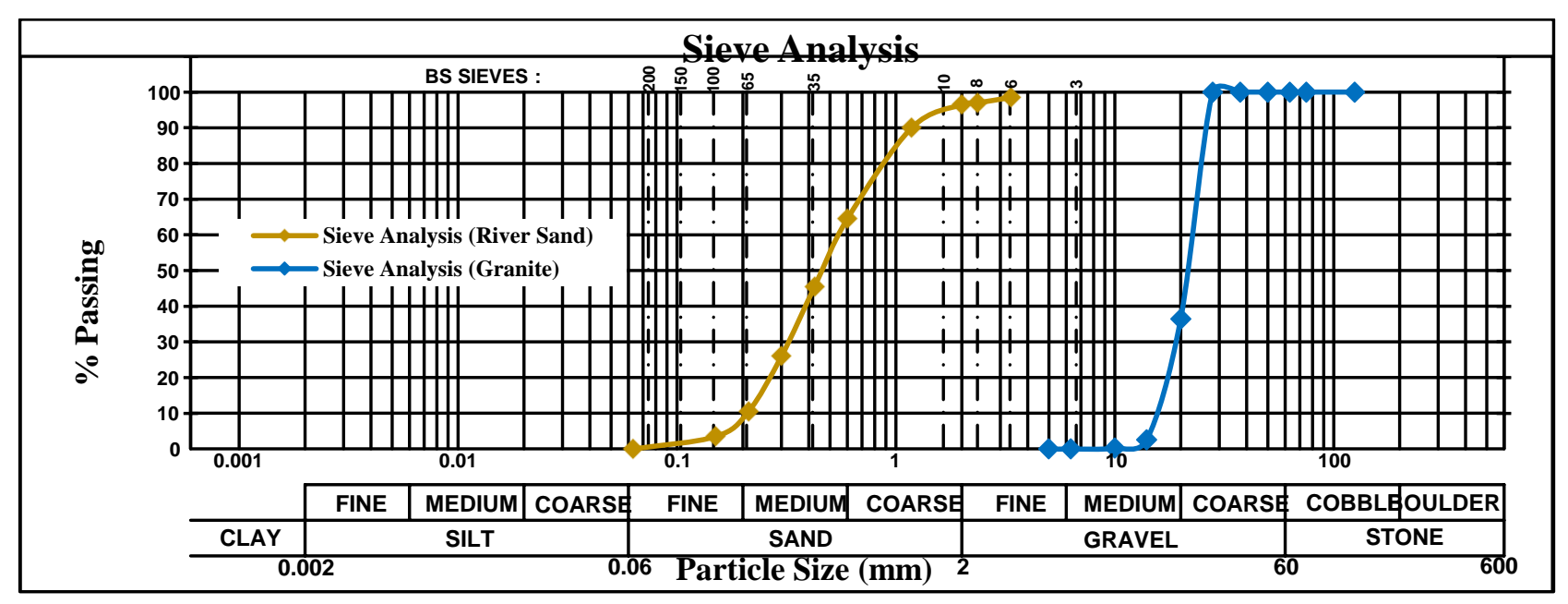

Figure 2. Particle size distribution of the Coarse and Fine aggregates used.

\begin{tabular}{llcc}
\hline $\mathrm{S} / \mathrm{N}$ & Physical test & Experimental Values & BS EN:2000 Specification \\
\hline 1 & Fineness (retained on $90 \mu \mathrm{m}$ sieve) $(\%)$ & 6.90 & $\leq 10$ \\
2 & Specific gravity & 3.15 & - \\
3 & Density $\left(\mathrm{kg} / \mathrm{m}^{3}\right)$ & 1450 & - \\
4 & Vicat setting time (minutes) & Initial setting time $=90$ & $\geq 45$ \\
& & Final setting time $=256$ & $\leq 375$ \\
\hline
\end{tabular}

TABle 1. Properties of grade 42.5 ordinary portland cement.

\begin{tabular}{llcc}
\hline $\mathrm{S} / \mathrm{N}$ & Physical test & Experimental Values & BS EN:2000 Specification \\
\hline 1 & Fineness modulus & 2.85 & $2.3-3.0$ \\
2 & Specific gravity & 2.65 & $2.63-2.67$ \\
3 & Apparent specific gravity & 2.68 & - \\
4 & Water absorption (\%) & 0.55 & - \\
5 & Coefficient of uniformity $(\mathrm{Cu})$ & 2.18 & $\leq 4$ \\
6 & Coefficient of curvature $(\mathrm{Cc})$ & 1.14 & $1-4$ \\
\hline
\end{tabular}

TABLE 2. Physical properties of River sand.

\begin{tabular}{llcc}
\hline S/N & Physical test & Experimental Values & BS EN:2000 Specification \\
\hline 1 & Aggregate impact value (AIV) $(\%)$ & $14.3 \%$ & $\leq 25 \%$ \\
2 & Specific gravity & 2.65 & $2.6-2.7$ \\
3 & Apparent specific gravity & 2.69 & - \\
4 & Water absorption (\%) & 0.61 & - \\
5 & Coefficient of uniformity $(\mathrm{Cu})$ & 1.57 & $\leq 4$ \\
6 & Coefficient of curvature (Cc) & 1.05 & $1-4$ \\
\hline
\end{tabular}

TABlE 3. Physical properties of coarse aggregate. 


\begin{tabular}{llc}
\hline $\mathrm{S} / \mathrm{N}$ & Properties & Values \\
\hline 1 & Specific gravity at $25^{\circ} \mathrm{C}$ & $1.00-1.02$ \\
2 & Boiling point & $100^{\circ} \mathrm{C}$ \\
3 & Viscosity at $25^{\circ} \mathrm{C}$ & $1200-2000 \mathrm{cps}$ \\
4 & pH at $25^{\circ} \mathrm{C}$ & $11.00-12.50$ \\
5 & Solubility in water & Miscible in water \\
6 & Appearance & Milky white \\
7 & Evaporation rate & Same as water \\
8 & Melting Point & Liquid \\
9 & Reactivity data & Stable \\
10 & Materials to avoid & Caustics and strong bases \\
11 & Hazardous content & None \\
\hline
\end{tabular}

TABLE 4. Properties of renolith (from the manufacturer).

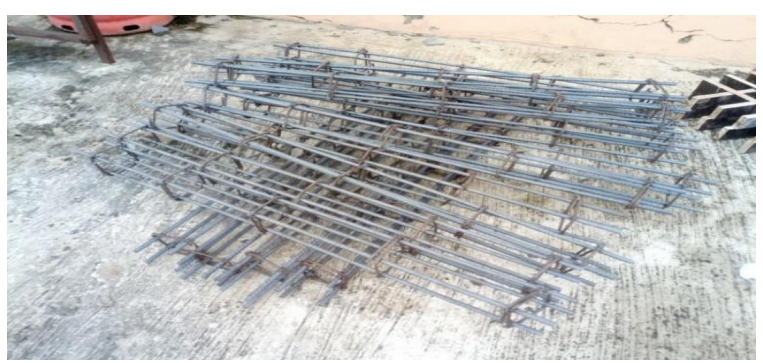

FiguRE 3. Y10 Beam Reinforcement.

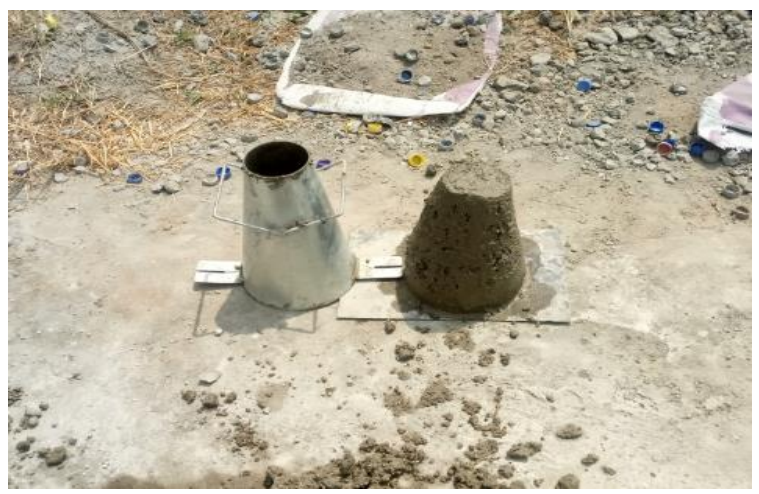

FigURE 4. Slump with EPS bead at $12.5 \%$ replacement.

chemically to form cementitious compound that contributes to improving strength of a poor soil. The liquid chemical stabilizer is one of the numerous chemical products in the market developed in Germany by Renolith chemical International from a blend of locally produced synthetic chemical products. According to the manufacturer, the water-soluble chemical is completely non-poisonous, non-combustible, noncorrosive, non-toxic, environmentally safe, and user friendly. See Table 4 for the physical properties as given by the manufacturer. Renolith chemical polymer additves (RCPA) is a synthetic compound with surface-active properties, which have been devised to change the hydrophilic (water adsorption) properties of clay minerals to those of hydrophobic (water repellent) ones, yet maintains the strength characteristics of the cement-stabilized soil. Few authors who have investigated the liquid polymer-based product (Renolith) concluded that it has significantly improved the workability of the cement stabilization process in a variety of road subgrade, rail, embankment, and other construction projects 12 . It also improves the properties of poor soils [13. Therefore, an experimental investigation was also carried out to ascertain its effect on a concrete mix.

\subsection{CONCRETE MIX AND PREPARATION}

The concrete mix was designed using the Department of Environment (DOE) method [14. Mix design of M30 (C25/C30) was adopted for this research. The mix ratio and water-cement ratio calculated was 1:1.6:3.8 and 0.54 respectively. The mix ratio indicates the amount of cement, fine and coarse aggregates used.

Six different concrete mixes were used. The conventional concrete mix (0\% EPS beads) and five other concrete mixes; $(12.5 \%, 25 \%, 37.5 \%, 50 \%$, and $100 \%$ of the aggregate replacement by the EPS). The samples were mixed according to the calculated ratios. The EPS beads were measured by volume while other constituents materials were measured by weight. See Table 5 for the mix ratio in $\mathrm{kg} / \mathrm{m} 3$ and the experimental flow chart in Fig. 5 .

\subsection{Slump TEST}

The concrete slump test gives the workability or consistency of fresh concrete and the ease with which it flows. The slumped concrete can take various shapes; it can be termed as true slump, shear slump or collapse slump. The slump test was done in an accordance with the BS 1881-102 [15] with a target slump of 30$60 \mathrm{~mm}$. Fig. 4 shows the true slump cone test at a $12.5 \%$ EPS replacement.

\subsection{Density test}

The densities were computed by taking the ratio of the average weight of the cubes at each percentage replacement of coarse aggregate with EPS beads to the volume of the cube $(100 \times 100 \times 100 \mathrm{~mm})$. The 


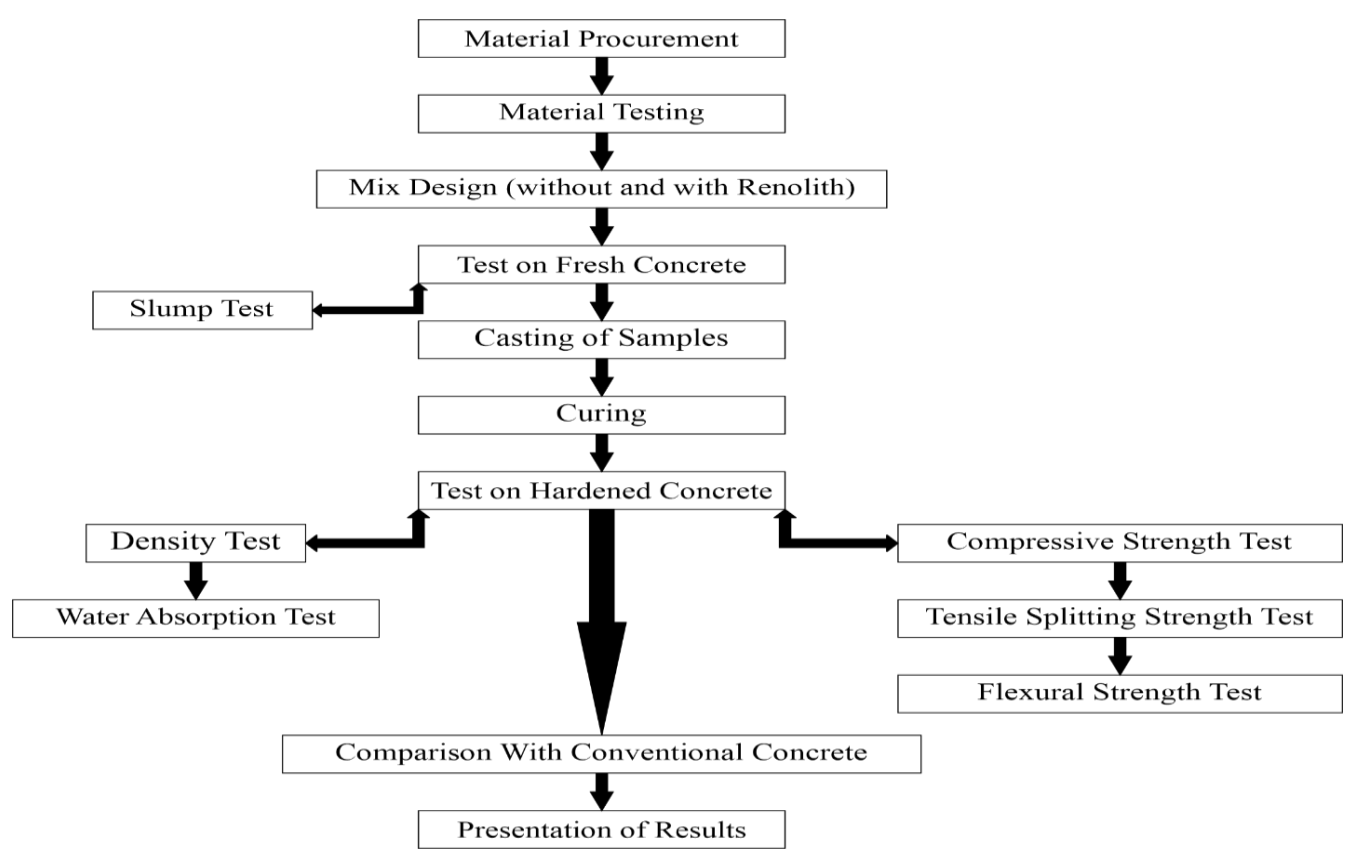

FiguRE 5. Flow chart representing the experimental procedure.

\begin{tabular}{cccccc}
\hline \% Replacement & $\begin{array}{c}\text { Cement } \\
\left(\mathrm{kg} / \mathrm{m}^{3}\right)\end{array}$ & $\begin{array}{c}\text { Fine Aggregate } \\
\left(\mathrm{kg} / \mathrm{m}^{3}\right)\end{array}$ & $\begin{array}{c}\text { Coarse Aggregate } \\
\left(\mathrm{kg} / \mathrm{m}^{3}\right)\end{array}$ & $\begin{array}{c}\text { Water } \\
\left(\mathrm{kg} / \mathrm{m}^{3}\right)\end{array}$ & $\begin{array}{c}\text { EPS beads by volume } \\
\left(\mathrm{kg} / \mathrm{m}^{3}\right)\end{array}$ \\
\hline 0 & 350 & 550 & 1340 & 190 & 0 \\
12.5 & 350 & 550 & 1172.5 & 190 & 167.5 \\
25 & 350 & 550 & 1005 & 190 & 335 \\
37.5 & 350 & 550 & 837.5 & 190 & 502.5 \\
50 & 350 & 550 & 670 & 190 & 670 \\
100 & 350 & 550 & 0 & 190 & 1340 \\
\hline
\end{tabular}

TABLE 5. Concrete mix design ratio.

weight of the cube specimen was measured after 28 days of curing and density estimated from eq. 1

$$
\text { Density }=\frac{\operatorname{Mass}(M)}{\operatorname{Volume}(V)}
$$

\subsection{WATER ABSORPTION TEST}

The water absorption (WA) test is used to determine the amount of water that can be absorbed by a sample under a specified condition. This was measured at 28 days of curing. The water absorption test was done in an accordance with the BS 1881-122 [16]. The weight of the hardened concrete samples after demolding was measured as $W_{0}$ and weight after 28 days of curing measured as $W_{1}$. The water absorption of each concrete mix was estimated from eq. 2

$$
W A=\left(\frac{\left(W_{1}-W_{0}\right)}{W_{0}} \times 100\right)
$$

\subsection{Compressive StREnGth TeSt}

The compressive strength test was carried out using the Compression Testing Machine ( $2000 \mathrm{kN}$ capacity) and in an accordance with the BS EN 12390-3 specification [17]. A total of 96 cubes $(100 \times 100 \times 100 \mathrm{~mm})$ were cast for the different mix designs. The test was carried out for different percentage mixes at a curing age of $7,14,21$ and 28 respectively. The load was appied at the rate of $0.45 \mathrm{MPa} / \mathrm{s}$. The compressive strength of each tested specimen was measured and recorded accordingly.

\subsection{Split TENSILE TEST}

This is an indirect test method for determining the tensile strength of concrete. The test consists of the application of a diametric compressive load along the entire length of a concrete cylinder until a failure occurs. This loading induces tensile stresses on the plane containing the applied load. A split tensile test strength was carried out on concrete, based on the BS EN 12390-6 [18, using a 75 by $150 \mathrm{~mm}$ cylindrical specimen. The split tensile strength was determined at 28 days of curing.

\subsection{Flexural strength test}

A flexural strength test was carried out in an accordance with the ASTM C293 / C293M-16 [19] on the reinforced concrete beam $(1000 \times 100 \times 100 \mathrm{~mm})$ specimens with high yield bars (Y10 steel bars). A total 


\begin{tabular}{ccc}
\hline \% Replacement coarse aggregate with EPS & $\begin{array}{c}\text { Slump value without RCPA } \\
(\mathrm{mm})\end{array}$ & $\begin{array}{c}\text { Slump value with RCPA } \\
(\mathrm{mm})\end{array}$ \\
\hline 0 & 30 & 30 \\
12.5 & 40 & 37 \\
25 & 75 & 72 \\
37.5 & 80 & 80 \\
50 & 95 & 97 \\
100 & Collapse & Collapse \\
\hline
\end{tabular}

TABLE 6. Slump results with and without RCPA.

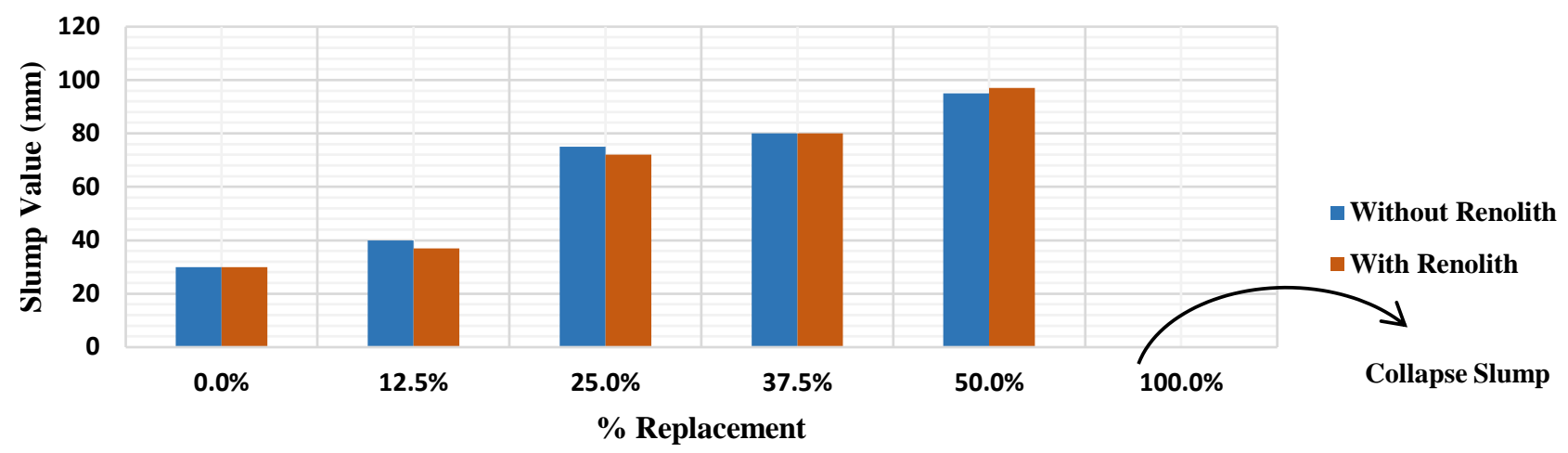

FiguRE 6. Slump chart with and without renolith at different \% replacement of coarse aggregate with EPS beam.

of 48 samples at different percentages of replacement were made and tested using the center-point loading system. The distance between the supports is kept at $800 \mathrm{~mm}$ throughout the experiment. The test was performed using a digital $100 \mathrm{kN}$ Universal Testing Machine (UTM) located at the ABUAD Structures laboratory.

\section{Results AND Discussion}

\subsection{Slump test}

With reference to Table 6 and Fig. 6 it was observed that the workability of the EPS concrete with and without Renolith chemical polymer additive (RCPA) increases with increasing EPS content. At $0 \%$ and $12.5 \%$ replacement, the concrete has a low workability (slump value between $10-40 \mathrm{~mm}$ ); While the $25 \%$ and $37.5 \%$ replacements indicate that the concrete has a medium workability (slump value between 50-90 mm). The slump at $50 \%$ and $100 \%$ replacement yielded 90mm and "collapse slump" respectively.This indicates a high workable concrete for which the slump test is not appropriate. Generally, the a addition of the RCPA slightly reduces the workability. This is due to the RCPA's capability of removing excess water content from the concrete mix.

\subsection{Density TEST}

Table 7 shows the computed densities for a concrete mix with and without addition of Renolith-polymer additive (RCPA) and Fig. 7 revealed that density decreases with an increase in EPS content added. This can be attributed to the decrease in the volume of coarse aggregate in the concrete mix. With reference to [1] and [6], a light-weight concrete is a concrete having a density between 160 to $1920 \mathrm{~kg} / \mathrm{m}^{3}$. So, a lightweight concrete was achieved at $50 \%\left(1817.5 \mathrm{~kg} / \mathrm{m}^{3}\right)$ and $100 \%\left(1030 \mathrm{~kg} / \mathrm{m}^{3}\right)$ for the mix without Renolith and $100 \%\left(1310 \mathrm{~kg} / \mathrm{m}^{3}\right)$ for the mix containing RCPA, respectively. While at the $0-37.5 \%$ replacement, dense concrete density $\left(>1920-2400 \mathrm{~kg} / \mathrm{m}^{3}\right)$ was achieved. It is believed that the RCPA adds a kind of "micro-rubberbands" around the concrete particles thereby increasing their bond interaction and making them more stronger than a normal concrete $\operatorname{mix.}$

\subsection{WATER ABsorption test}

Table 8 and Fig. 8 shows the water absorption of the concrete with and without the RCPA at different \% of replacement of the coarse aggregate with the EPS beads. For the conventional concrete mix ( $0 \%$ replacement), the water absorption measured was $3.9 \%$. The $25 \%$ replacement showed the lowest absorption rate $(3.7 \%)$. While the $100 \%$ replacement has the highest water absorption capacity $(13.4 \%)$. Generally, the water absorption decreases (about $24.3 \%$ on the average) with the addition of the RCPA to the concrete mix. The EPS beads are naturally hydrophobic (i.e., they do not absorb water). The possibility for a high water absorption in the EPS concrete may be due to the decrease in the density of the concrete which in turn increases its porosity. According to "the concrete Society" 20, water absorption should be in the range 


\begin{tabular}{cccccc}
\hline \multicolumn{2}{c}{ Without RCPA } & \multicolumn{3}{c}{ With RCPA } \\
\hline \% of EPS replacement & $\begin{array}{c}\text { Weight } \\
(\mathrm{kg})\end{array}$ & $\begin{array}{c}\text { Density } \\
\left(\mathrm{kg} / \mathrm{m}^{3}\right)\end{array}$ & $\begin{array}{c}\text { Weight } \\
(\mathrm{kg})\end{array}$ & $\begin{array}{c}\text { Volume } \\
\left(\mathrm{m}^{3}\right)\end{array}$ & $\begin{array}{c}\text { Density } \\
\left(\mathrm{kg} / \mathrm{m}^{3}\right)\end{array}$ \\
\hline 0 & 2.458 & 2458 & 2.554 & 0.001 & 2554 \\
12.5 & 2.248 & 2248 & 2.456 & 0.001 & 2456 \\
25 & 2.076 & 2076 & 2.287 & 0.001 & 2287 \\
37.5 & 1.943 & 1943 & 2.210 & 0.001 & 2210 \\
50 & 1.818 & 1818 & 1.984 & 0.001 & 1984 \\
100 & 1.030 & 1030 & 1.310 & 0.001 & 1310 \\
\hline
\end{tabular}

TABLE 7. Computed densities at different \% replacement of coarse aggregate with EPS beads.

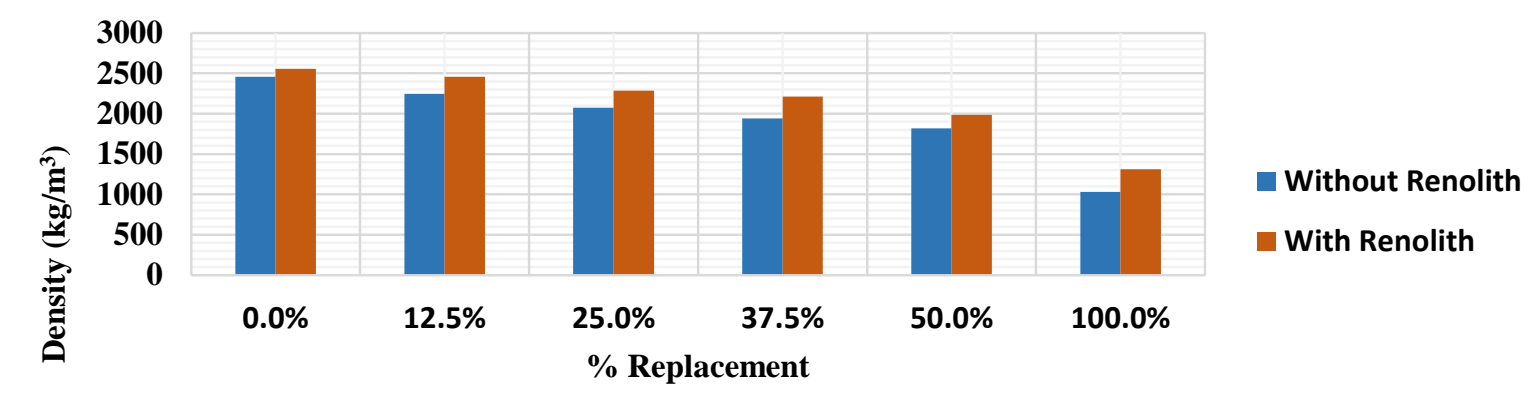

FiguRE 7. Density chart with and without renolith at different $\%$ replacement of coarse aggregate with EPS beam.

\begin{tabular}{ccc}
\hline \% of EPS replacement & $\begin{array}{c}\text { Water absorption (\%) } \\
\text { Without RCPA }\end{array}$ & $\begin{array}{c}\text { Water absorption (\%) } \\
\text { With RCPA }\end{array}$ \\
\hline 0 & 3.9 & 3.9 \\
12.5 & 4.3 & 3.1 \\
25 & 3.7 & 3.3 \\
37.5 & 4.9 & 3.2 \\
50 & 4.5 & 3.9 \\
100 & 13.4 & 8.8 \\
\hline
\end{tabular}

TABLE 8. Computed densities at different \% replacement of coarse aggregate with EPS beads.

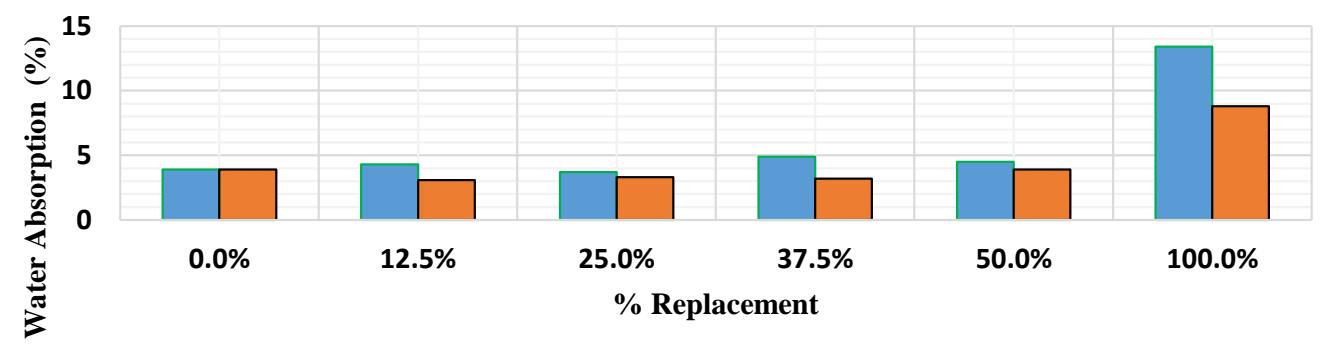

$\square$ Without Renolith $\quad \square$ With Renolith

FIGURE 8. Absorption with and without renolith at different \% replacement of coarse aggregate with EPS beam. 


\begin{tabular}{ccccc}
\hline Number of days & 7 & 14 & 21 & 28 \\
\hline \% replacement & \multicolumn{4}{c}{$\left(\mathrm{N} / \mathrm{mm}^{2}\right)$} \\
\hline 0 & 33.0 & 34.0 & 37.5 & 44.0 \\
12.5 & 20.0 & 26.5 & 30.5 & 34.5 \\
25 & 24.5 & 28.0 & 29.0 & 33.5 \\
37.5 & 13.0 & 15.0 & 15.5 & 22.5 \\
50 & 15.0 & 17.0 & 19.0 & 22.0 \\
100 & 6.5 & 8.0 & 8.0 & 8.5 \\
\hline
\end{tabular}

TABLE 9. C.S of EPS at different \% replacement.

\begin{tabular}{ccccc}
\hline Number of days & 7 & 14 & 21 & 28 \\
\hline \% replacement & \multicolumn{4}{c}{$\left(\mathrm{N} / \mathrm{mm}^{2}\right)$} \\
\hline 0 & 35.0 & 36.0 & 39.5 & 46.0 \\
12.5 & 29.0 & 31.5 & 36.5 & 39.5 \\
25 & 26.5 & 28.0 & 32.0 & 35.5 \\
37.5 & 23.0 & 23.0 & 25.5 & 26.5 \\
50 & 19.0 & 21.0 & 22.6 & 22.5 \\
100 & 10.5 & 13.8 & 14.2 & 14.5 \\
\hline
\end{tabular}

TABLE 10. C.S of EPS with RCPA .

of $6-7 \%$. All design mixes met this criteria except at a $100 \%$ replacement of the ESP.

\subsection{Compressive strength (C.S) test}

The results of compressive strength test are presented in Tables 9 and 10 . The compressive strength of all concrete mixes with and without the RCPA increased with the increasing time of curing as shown in Fig. 9 . At $0 \%$ and $12.5 \%$ replacement and 28 days of curing, compressive strength was $44 \mathrm{~N} / \mathrm{mm}^{2}$ (without RCPA) and $34.5 \mathrm{~N} / \mathrm{mm}^{2}$ (i.e., $78 \%$ of the control), respectively. Other percentage replacements; (i.e., $25 \%$, $37.5 \%, 50 \%$ and $100 \%$ ) gave compressive strength values of about $76-19 \%$ of the control specimen $(0 \%$ replacement). Similarly, for the concrete mix with the RCPA and $12.5 \%$ EPS beads, the compressive strength is about $85.9 \%$ of the control specimen at 28 days. Other replacements (i.e., $25 \%$, 37.5\%, $50 \%$ and $100 \%$ ) gave compressive strength values of about $79.2-31.5 \%$ of the control specimen at 28 days of curing. The result showed that there is a decrease in compressive strength due to the increase in the percentage of the EPS content. But the addition of the RCPA tends to increase the compressive strength. However, at $50 \%$ replacement of the coarse aggregate with the EPS beads, the concrete sample still satisfies the strength requirements (above $17.25 \mathrm{~N} / \mathrm{mm}^{2}$ ) for a light-weight concrete to be used structurally as specified by ACI 311-05 [21]. The reduced strength can be attributed to the reduction in density of the concrete.

\subsection{Split tensile test}

The result of tensile split test with and without the addition of RCPA are presented in Tables 11 and 12 . Fig. 10 also showed the plot of the tensile strength

\begin{tabular}{ccccc}
\hline Number of days & 7 & 14 & 21 & 28 \\
\hline \% replacement & \multicolumn{4}{c}{$\left(\mathrm{N} / \mathrm{mm}^{2}\right)$} \\
\hline 0 & 4.40 & 5.10 & 5.85 & 7.65 \\
12.5 & 3.80 & 3.95 & 4.10 & 5.00 \\
25 & 4.45 & 4.65 & 6.15 & 6.90 \\
37.5 & 3.55 & 4.50 & 5.15 & 5.95 \\
50 & 5.10 & 5.20 & 5.85 & 7.20 \\
100 & 2.80 & 2.95 & 3.25 & 3.40 \\
\hline
\end{tabular}

TABLE 11. T.S. of EPS without RCPA.

\begin{tabular}{ccccc}
\hline Number of days & 7 & 14 & 21 & 28 \\
\hline \% replacement & \multicolumn{4}{c}{$\left(\mathrm{N} / \mathrm{mm}^{2}\right)$} \\
\hline 0 & 4.60 & 5.30 & 6.20 & 8.30 \\
12.5 & 4.10 & 4.75 & 5.10 & 6.60 \\
25 & 4.70 & 4.95 & 6.80 & 7.10 \\
37.5 & 3.80 & 4.55 & 6.25 & 6.45 \\
50 & 4.10 & 5.10 & 5.65 & 6.30 \\
100 & 3.85 & 4.25 & 4.25 & 4.40 \\
\hline
\end{tabular}

TABLE 12. T.S. of EPS with RCPA.

against the curing days with and without the RCPA. Generally, there is an increase in tensile strength with the addition of the RCPA, but a decrease with the addition of the EPS. The polymer additive tends to eliminate voids and segregation of concrete particles leading to an increased bonding interaction.

\subsection{Flexural strength (F.S) test}

The summary of the results for the Modulus of Rupture $(\mathrm{MoR})$ is presented in Tables 13 and 14 Fig. 11 showed the crack pattern of the tested EPS reinforced concrete beam after the flexural strength test. Fig. 12 also showed that the MoR of all concrete mixes with and without the RCPA increases with the increase of the concrete's age. The average Modulus of Rupture (MoR) for all mix designs (without the addition of the RCPA) is between $7.5-9.3 \mathrm{~N} / \mathrm{mm}^{2}$ and $8-10.7 \mathrm{~N} / \mathrm{mm}^{2}$ for the concrete mix containing the RCPA. The MoR for all concrete mixes is between $10-15 \%$ of the compressive strength as specified by NRMCA-Concrete in Practice 16 [22] indicating the potential of the ESP as a good materials for both light- and dense-weight concrete.

\section{Conclusions}

The following conclusions are drawn from this research:

(1.) The re-using of the EPS from a landfill in the concrete production can help to solve environmental problems, reducing the cost of construction, and disposal of the EPS waste.

(2.) The increase in water absorption at $100 \%$ replacement of aggregates with EPS is accompanied with decrease in mechanical properties of EPS concrete. 


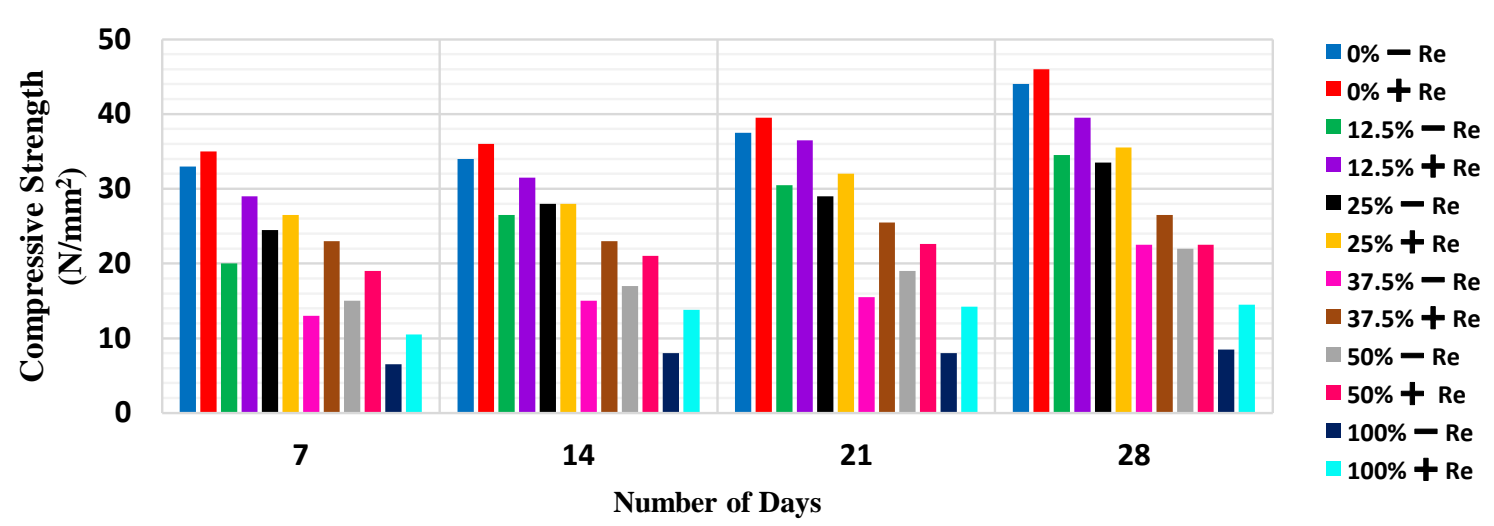

Figure 9. Compressive strength chart with and without renolith at different $\%$ replacement of coarse aggregate with EPS beam.

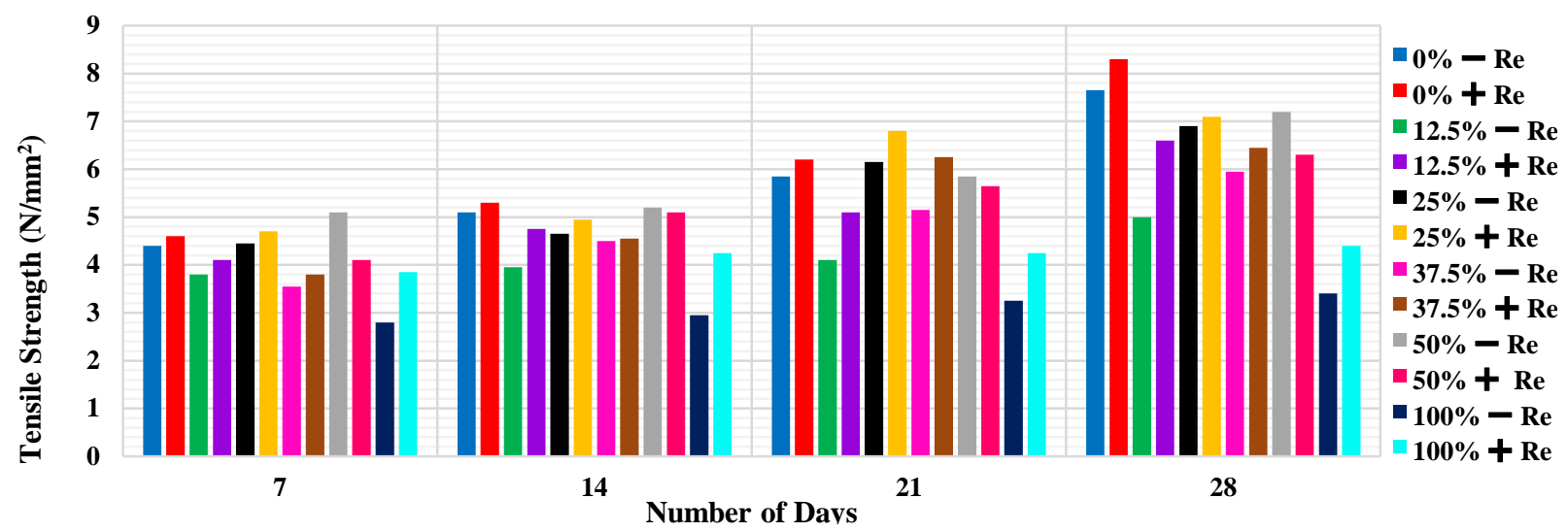

FigURE 10. Tensile strength chart with and without renolith at different $\%$ replacement of coarse aggregate with EPS beam.

\begin{tabular}{cclcc}
\hline Number of days & 7 & 14 & 21 & 28 \\
\hline \% replacement & \multicolumn{4}{c}{$\left(\mathrm{N} / \mathrm{mm}^{2}\right)$} \\
\hline 0 & 8.8 & 9.2 & 9.8 & 10.7 \\
12.5 & 7.1 & 7.6 & 8.2 & 8.7 \\
25 & 7.4 & 8.1 & 8.8 & 9.3 \\
37.5 & 6.0 & 6.8 & 7.9 & 8.4 \\
50 & 6.2 & 6.3 & 7.9 & 8.6 \\
100 & 4.1 & 4.7 & 5.1 & 5.5 \\
\hline
\end{tabular}

TABLE 13. F.S. of EPS with RCPA.

\begin{tabular}{ccccc}
\hline Number of days & 7 & 14 & 21 & 28 \\
\hline \% replacement & \multicolumn{4}{c}{$\left(\mathrm{N} / \mathrm{mm}^{2}\right)$} \\
\hline 0 & 8.4 & 8.7 & 9.0 & 9.3 \\
12.5 & 6.2 & 6.4 & 7.2 & 7.5 \\
25 & 5.9 & 7.3 & 7.5 & 7.8 \\
37.5 & 5.2 & 5.4 & 7.3 & 7.5 \\
50 & 4.8 & 5.4 & 7.5 & 7.9 \\
100 & 3.3 & 3.7 & 4.1 & 4.3 \\
\hline
\end{tabular}

TABLE 14. F.S. of EPS without RCPA.

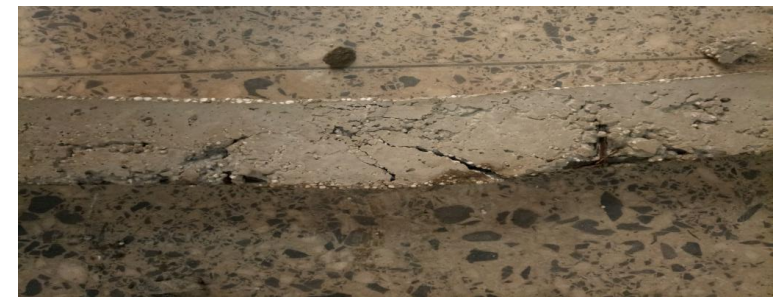

FigURE 11. Crack pattern of reinforced concrete beam with EPS as replacement aggregate.

(3.) The replacement of coarse aggregate with the EPS beads showed a positive application as an alternative material for a construction of structural light-weight members especially for high-rise structures where the load is an important factor to be reduced. Based on the compressive, split tensile and flexural strength test results; the $12.5 \%$ and $25 \%$ replacement of coarse aggregate with the EPS beads can be used to make a dense concrete since their densities and strengths are within specifications. At the $37.5 \%$ and $50 \%$ replacement, a light-weight concrete was achieved and at a $100 \%$ replacement of aggregates with the EPS beads, the results did not meet the minimum strength requirements for it to be used for structural applications. 


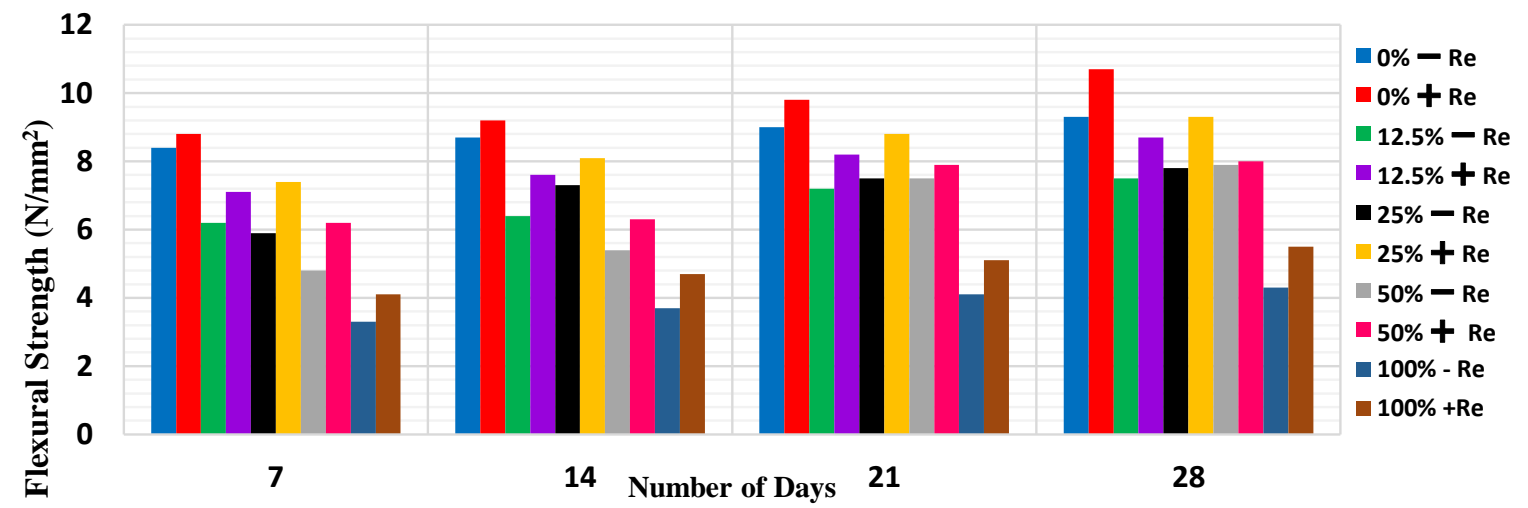

FiguRE 12. Flexural strength chart with and without renolith at different $\%$ replacement of coarse aggregate with EPS beam.

(4.) An experimental investigation has proven that the addition of the Renolith chemical polymer additive (RCPA) to the concrete mix has a positive influence on the physical and mechanical properties of the EPS concrete. This strength improvement is reached at the replacement of aggregates with EPS beads of $50 \%$ for a light-weight concrete and $25 \%$ for a dense-weight concrete, thereby reducing the cost of construction.

(5.) Further studies can be carried out on the effects of heat and other polymer admixtures on the physical and mechanical properties of the high-strength EPS concrete.

\section{ACKNOWLEDGEMENTS}

The results in this research were supported by the ABUAD Concrete and Structures laboratory. Thanks to all the technologists.

\section{REFERENCES}

[1] V. Oyenuga. Simplified Reinforced Concrete Design (A Consultant/Computer-Based Approach). ASROS Ltd, Lagos, 2nd edn., 2001.

[2] Styro. Styro beads. https://www.styrouae.com/ insulation-and-construction/styro-bead/ Accessed: 22 November 2018.

[3] S. Jayalekshmi, M. A. Reddy. Studies on polymer based chemical treated clay soil. International Journal of Engineering Research \& Technology 1(10):1 - 3, 2012.

[4] A. Quadri, A. Olagbaye, M. Abdulhameed. Renolith appraisal on lateritic soils along Oshogbo-Iwo road in southwest Nigeria. International Journal of Science and Qualitative Analysis 4(1):1 - 6, 2018. DOI:10.11648/j.ijsqa.20180401.11.

[5] S. Jamal, P. Kumar. An experimental study on renolith treated black cotton soil for subgrade pavements. International Journal of Science and Research 2015.

[6] A. R. Kumar, P. Prakash. Mechanical properties of structural light weight concrete by blending cinder \& LECA. International Advanced Research Journal in Science, Engineering Technology 2(10):64 - 67, 2015. DOI:10.17148/IARJSET.2015.21013
[7] S. Hedjazi. Compressive strength of lightweight concrete. In P. Kryvenko (ed.), Compressive Strength of Concrete, chap. 3. IntechOpen, Rijeka, 2020. DOI:10.5772/intechopen.88057.

[8] British Standard (BS) 197-1 - Cement Composition, Specification and Conformity Criteria for Common Cements. Standard, British Standards Institution, London, 2000.

[9] British Standard (BS) 812-103.1 - Testing Aggregates - Part 103: Methods for Determination of Particle Size Distribution - Section 103.1 Sieve Tests. Standard, British Standards Institution, London, 1985.

[10] British Standard (BS) 812-Part 2 - Testing Aggregates - Part 2: Methods of Determination of Density. Standard, British Standards Institution, London, 1995.

[11] British Standard (BS) 12-112 - Testing Aggregates Part 112: Methods for Determination of Aggregate Impact Value (AIV). Standard, British Standards Institution, London, 1990.

[12] S. Anoop, G. Prashant. Evaluation of renolith as a subgrade stabilizer. In 50th Indian Geotechnical Conference. Pune, Maharashatra, 2015.

[13] Y. Que, Y. Q. Lin, F. Z. Gong. Experimental study on the performance of compound improved HLLS (High Liquid Limit Soil) with various curing agents. In International Symposium on Advanced Material Research, vol. 753 of Key Engineering Materials, pp. 300 - 304. Trans Tech Publications Ltd, 2017. DOI:10.4028/www.scientific.net/KEM.753.300

[14] Department of Environmental Design Method (DOE). Method of concrete mix design.

http://www.engineeringenotes.com. Accessed: 29 December 2019.

[15] British Standard (BS) 1881-102: Testing Concrete Part 102: Method for Determination of Slump. Standard, British Standards Institution, London, 1983.

[16] British Standard (BS) 1881-122:2011: Testing Concrete - Part 122: Method for Determination of Water Absorption. Standard, British Standards Institution, London, 1983

[17] BS EN 12390-3: 2019: - Testing Hardened Concrete Part 3: Compressive Strength of Test Specimens. Standard, British Standards Institution, London, 2002. 
[18] BS EN 12390-6 - Testing Hardened Concrete - Split Tensile Strength of Test Specimens. Standard, British Standards Institution, London, 2000.

[19] ASTM C293/C293M-16 - Standard Test Method for Flexural Strength of Concrete (Using Simple Beam with Center-Point Loading). Standard, American Society for Testing and Materials, West Conshohocken, 2016.

[20] The Concrete Society. Water asoption for lightweight concrete. https://www. concrete.org.uk. Accessed: 9 December 2019.
[21] ACI 311-05 - Specifications for Structural Concrete. Standard, American Concrete Institute, Farmington Hills, 2000.

[22] Concrete in practice: CIP16 - Flexural Strength Concrete. Technical information, National Ready Mix Concrete Association, 2000. 